\title{
Gene expression of luteinizing hormone receptor and steroidogenic enzymes during Leydig cell development
}

\section{T O Abney and J Zhai}

Department of Physiology and Endocrinology, Medical College of Georgia, Augusta, Georgia 30912, USA

(Requests for offprints should be addressed to T O Abney, Department of Physiology and Endocrinology, Medical College of Georgia, Augusta, Georgia 30912, USA)

\section{ABSTRACT}

Testicular Leydig cells (LC) are rapidly and selectively destroyed by an injection of ethane dimethane sulfonate (EDS). LC regeneration occurs in the testis of the EDS-treated rats from the differentiation of the precursor Leydig cells (PLC). This study was designed to investigate the patterns of change in the mRNAs for the luteinizing hormone receptor (LHR) and the steroidogenic enzymes, cholesterol side chain cleavage $\left(\mathrm{P}-450_{\text {scc }}\right)$ and $17 \alpha$-hydroxylase $\left(\mathrm{P}-450_{17 \alpha}\right)$ during LC regeneration from PLCs. Mature (60 days of age) Sprague-Dawley male rats received a single intraperitoneal injection of EDS and were killed at different times between days 2 and 60 posttreatment. PLC- and LC-enriched fractions were isolated from the testes of the EDS-treated rats and age-matched control rats using a collagenase digestion-Percoll gradient method. Total RNA was extracted from these cell populations and subjected to Northern blot analysis.

The LC fraction isolated from testes of control rats expressed four major transcripts of the LHR, sized $1 \cdot 8,2 \cdot 5,4 \cdot 2$ and $7 \cdot 0 \mathrm{~kb}$. The undifferentiated PLC fraction from controls expressed only a truncated form, the $1.8 \mathrm{~kb}$ transcript. This truncated LHR transcript was also the only LHR mRNA species detected in PLCs at day 2 post-EDS treatment. In contrast, all four transcripts of the LHR were detected in the PLC fraction at day 10 post-EDS treatment. The levels of the full length $7 \cdot 0 \mathrm{~kb}$ transcript increased thereafter and reached a peak between days 24 and 36 post-EDS treatment in the PLC fraction. Concomitant with the increase in the $7.0 \mathrm{~kb}$ transcript, the truncated $1.8 \mathrm{~kb}$ transcript decreased in amount and reached a nadir between days 16 and 36 post-treatment. The changes observed in this cell fraction reflect the process of differentiation of PLCs into LCs. At day 45 post-EDS treatment, the level of the $7 \cdot 0 \mathrm{~kb}$ transcript decreased while the $1.8 \mathrm{~kb}$ form increased in the PLC fraction, reflecting the completion of LC regeneration from this cell fraction. By day 60 post-EDS treatment, the levels of the $1.8 \mathrm{~kb}$ transcript rose to the value observed in undifferentiated control PLCs and the other transcripts were no longer detected in the PLC fraction, indicating that cells in the PLC fraction were again in an undifferentiated stage.

Messenger RNAs for both the steroidogenic enzymes, $\mathrm{P}-450_{\text {scc }}$ and $\mathrm{P}-450_{17 \alpha}$ were expressed in the control LC fraction. Neither of these two mRNAs were detected in the PLC fraction of the control rats. $\mathrm{P}-450_{\text {scc }}$ and $\mathrm{P}-450_{17 \alpha}$ mRNAs were first expressed in the PLC fraction at day 10 post-EDS treatment. Thereafter, the levels of $\mathrm{P}-450_{\mathrm{scc}}$ and $\mathrm{P}-450_{17 \alpha}$ mRNAs increased in the PLC fraction and reached a peak between days 24 and 36 and days 24 and 45 post-EDS treatment respectively. $\mathrm{P}-450_{\text {scc }}$ and $\mathrm{P}-450_{17 \alpha}$ mRNAs were no longer expressed in the PLC fraction at day 60 post-EDS treatment. These patterns also reflect the process of differentiation of PLCs into functional LCs.

These results demonstrate for the first time that PLCs in the control testis are undifferentiated and do not express functional LHR and steroidogenic enzymes or their mRNAs. The PLCs are characterized, however, by the expression of a truncated $1.8 \mathrm{~kb}$ transcript of the LHR mRNA. Functional LHR and steroidogenic enzymes are expressed in PLCs only during their differentiation into LCs after EDS treatment. Subsequent to LC regeneration, the PLCs return to an undifferentiated stage.

Fournal of Molecular Endocrinology (1998) 20, 119-127 


\section{INTRODUCTION}

The principal function of testicular Leydig cells (LC) is the production of androgens, with testosterone being the most important product. The synthetic pathway of testosterone in LCs involves several cytochrome P-450 enzymes. The first step, catalyzed by $\mathrm{P}-450_{\text {scc }}$ (side chain cleavage enzyme), is the conversion of cholesterol to pregnenolone (Privalle et al. 1983, Hall 1985). A single enzyme, P-450 $17 \alpha$ (17 $\alpha$-hydroxylase), subsequently catalyzes two reactions in the synthetic pathway which involves $17 \alpha$-hydroxylation and cleavage of the $\mathrm{C}_{17-20}$ bond (Nakajin et al. 1984, Hall 1991). The expression of steroidogenic enzymes involved in testosterone synthesis is a functional characteristic of mature LCs in the testis.

Differentiated morphological structure and biochemical function of LCs are dependent upon luteinizing hormone (LH) secreted from the pituitary (Teerds et al. 1989, Russell et al. 1992). The receptor for $\mathrm{LH}$ (LHR) is located in the plasma membrane and belongs to a G-protein-coupled receptor family. The acute effect of $\mathrm{LH}$ on LC function is mediated mainly by the cAMP-protein kinase A pathway (Bartke et al. 1978) and the long term tropic effect of $\mathrm{LH}$ on LC structure and function requires both RNA and protein synthesis (Payne et al. 1992). The LHR is expressed primarily in the LCs; however, immunohistochemical studies have shown the presence of $\mathrm{LH} /$ chorionic gonadotropin (CG) receptors in the vascular endothelial cells of the testis (Misrahi et al. 1996). Reiter et al. (1995) also demonstrated the existence of functional LHR in the rat prostate, mainly in the ventral lobe.

Several transcripts of LHR mRNA have been detected in both the testis and ovary, varying from 1.2 to $7 \cdot 6 \mathrm{~kb}$ in length (Saez 1994). This phenomenon may result from alternative splicing or multiple transcription start sites (Segaloff et al. 1990, Segaloff \& Ascoli 1993). Transcripts larger than the full length $2 \cdot 1 \mathrm{~kb}$ cDNA can be translated into the receptor and the $7 \cdot 0 \mathrm{~kb}$ transcript has been shown to correlate with functional receptor levels in cells (Vihko et al. 1992, Segaloff \& Ascoli 1993). The 1.2 and $1.8 \mathrm{~kb}$ transcripts encode for truncated forms of the LHR corresponding to the extracellular domain which remain trapped within the cells rather than being secreted (Segaloff \& Ascoli 1993).

Although the development of LCs in the testis and the regulation of this process have been studied for many years, they are not fully understood. The adult-type LCs are believed to be derived from the differentiation of the precursor Leydig cells (PLC) during puberty (Tapanainen et al. 1984,
Mendis-Handagama et al. 1987). It is still unclear, however, what are the morphological and biochemical processes involved in PLC differentiation. In recent years, ethane dimethane sulfonate (EDS), an alkylating agent which selectively destroys LCs in the mature testis, has been used in studies of LC development. Within two days after a single injection of EDS, all LCs have disappeared from the testis (Kerr et al. 1985, Morris et al. 1986). LC regeneration occurs between two and four weeks after EDS treatment from the differentiation of the PLCs (Jackson et al. 1986, Kerr et al. 1987). The present study utilized purified LC and PLC fractions from the EDS-treated rats to detect and determine the patterns of change in LHR and steroidogenic enzyme mRNAs during PLC differentiation. These results provide an insight into the process of PLC differentiation into functional LCs.

\section{MATERIALS AND METHODS}

\section{Animals and treatment}

Mature (60 days of age) male Sprague-Dawley rats were purchased from Harlan Industries (Indianapolis, IN, USA) and housed in a 12-h light/dark environment with water and rat chow available ad libitum. Animals received a single intraperitoneal injection of EDS $(100 \mathrm{mg} / \mathrm{kg}$ body weight) and were killed by decapitation on day 2 , $10,16,20,24,36,45$ or 60 after treatment. Agematched controls were also killed at each of these times. Each experiment was performed two to seven times, using ten rats per group. This institution's animal use committee approved all experimental protocols to which these animals were subjected.

\section{Chemicals and solutions}

EDS, which is not commercially available, was synthesized as described previously (Myers \& Abney 1990) and dissolved in dimethyl sulfoxide and water $(1: 1 \mathrm{v} / \mathrm{v})$. HEPES, soybean trypsin inhibitor, collagenase (type L), Percoll, dextran sulfate (molecular weight 500000 ), diethyl pyrocarbonate (DEPC) and MOPS (3-( $N$-morpholino)propane sulfonic acid) were purchased from Sigma Chemical Co. (St Louis, MO, USA). Sodium chloride, sodium citrate, BSA (fraction V), sodium bicarbonate, chloroform, formaldehyde, SDS (sodium dodecyl sulfate) and Ficoll were purchased from Fisher Scientific (Pittsburgh, PA, USA). Dulbecco's Modified Eagle's Medium (DMEM) and Ham's F12 were obtained from Gibco BRL (Grand Island, NY, USA). The oligolabeling 
kit, Nick column Sephadex G-50 and density marker beads were provided by Pharmacia Inc. (Piscataway, NJ, USA). RNAzol was purchased from Biotex Laboratories, Inc. (Houston, TX, USA). Genescreen plus hybridization transfer membranes were products of New England Nuclear (Boston, MA, USA). $\alpha^{32} \mathrm{P}-\mathrm{dCTP}$ was obtained from ICN Pharmaceutical Inc. (Costa Mesa, CA, USA). The rat LHR cDNA probe was a gift from Dr A J W Hsueh at the University of California, San Diego, USA. Plasmid with rat P-450 scc $_{\text {cDNA }}$ insert was a gift from Dr J S Richards at Baylor College of Medicine (Houston, TX, USA). The cDNA for $\mathrm{P}-450_{17 \alpha}$ was provided by $\mathrm{Dr} \mathrm{RH}$ Fevold at the University of Montana and generously given by Dr V B Mahesh (Medical College of Georgia, Augusta, GA, USA). Escherichia coli containing pHcGAPD (a plasmid with an insert for glyceraldehyde phosphate dehydrogenase) was purchased from American Type Culture Collection (Rockville, MD, USA).

\section{Cell isolation}

Testes were removed from the animals and placed on ice in a 1:1 mixture of DMEM and F12 buffered with $1.2 \mathrm{~g}$ sodium bicarbonate/l and $15 \mathrm{mM}$ HEPES containing $0 \cdot 1 \%$ BSA and $25 \mathrm{mg}$ soybean trypsin inhibitor/l, pH $7 \cdot 4$ (DMEM/F12). Testes were digested in DMEM/F12 with $0.625 \mathrm{mg}$ collagenase $/ \mathrm{ml}$. The procedures utilized to isolate the LC and PLC fractions were carried out essentially as described by Klinefelter et al. (1987) and Hardy et al. (1990). Briefly, dispersed interstitial cells were separated from the tubular compartment by filtration through surgical gauze and washed twice in DMEM/F12 by centrifugation at $800 \boldsymbol{g}$ to sediment the cells and remove the collagenase. The interstitial cells were suspended in $55 \%$ Percoll and centrifuged at $20000 \boldsymbol{g}$ for $60 \mathrm{~min}$ at $4{ }^{\circ} \mathrm{C}$ in a Beckman JA-20 fixed angle rotor. A gradient was thereby generated in which cells banded in the regions of their iso-density. A gradient containing density marker beads was centrifuged simultaneously to provide a guide for fractionation. A gradient fraction containing PLCs was removed from the Percoll gradient between a density of $1.064-1.070 \mathrm{~g} / \mathrm{ml}$ and a gradient fraction enriched in LCs was collected from a density heavier than $1.070 \mathrm{~g} / \mathrm{ml}$. Each fraction was diluted with DMEM/F12 and centrifuged at $800 \boldsymbol{g}$ to remove the Percoll while pelleting the cells. The purity of PLCs and LCs isolated by this procedure was reported previously to be $90 \%$ and $93 \%$ respectively, based on $3 \beta$-hydroxysteroid dehydro-

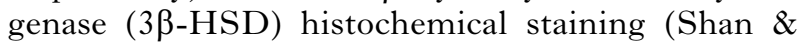

Hardy 1992). We also observed that greater than $90 \%$ of the cells in the control LC fractions were darkly stained, indicating a high percentage of $3 \beta$-HSD-positive cells. Identification of the various cell-types in the PLC fraction was not performed, but the majority of cells in the control PLC fraction were lightly stained. By contrast, in the day 20 post-EDS-treated PLC fraction which contains differentiating LCs, we observed greater than $90 \%$ staining overall; however, only about $33 \%$ of these cells stained deeply, while the remainder stained lightly. Such a variable intensity of cell staining suggests that the PLC fraction contains PLCs that are in different stages of differentiation into LCs.

\section{Northern blot analysis}

Total RNA was extracted from the LC- or PLCenriched fractions with RNAzol and the RNA concentration was determined by UV absorbance at $260 \mathrm{~nm}$. Twenty micrograms RNA from each cell fraction were utilized for Northern blot analysis. The procedures for Northern blot were carried out essentially as described by Shan \& Hardy (1992). Briefly, RNA was electrophoresed on a $0.66 \mathrm{M}$ formaldehyde agarose gel in $1 \times$ MOPS buffer. RNA was transferred onto Genescreen hybridization transfer membranes in $10 \times \mathrm{SSC}$ for $16-24 \mathrm{~h}$. Prehybridization of the membranes was performed at $42{ }^{\circ} \mathrm{C}$ for $2-4 \mathrm{~h}$ in $50 \%$ formamide, $5 \times \mathrm{SSPE}, 5 \times$ Denhardt's solution, $1 \% \mathrm{SDS}, 10 \%$ dextran sulfate with the addition of $100 \mu \mathrm{g} / \mathrm{ml}$ denatured sheared salmon sperm DNA. Hybridizations were carried out overnight in fresh buffer with ${ }^{32} \mathrm{P}$-labeled cDNA probes as the template. Membranes were washed and exposed to Kodak X-ray film at $-80{ }^{\circ} \mathrm{C}$ for an appropriate time between 24 and $48 \mathrm{~h}$. Quantification of mRNA was performed by scanning the autoradiograms with an Ultrascan XL Laser densitometer and the target mRNA levels were expressed relative to that of the internal standard, glyceraldehyde phosphate dehydrogenase (GAPD).

\section{Statistical analysis}

Data were subjected to ANOVA and Dunnett's and Fisher's LSD $t$-test to detect statistical differences. A $P$ value $\leq 0.05$ was considered to be statistically significant.

\section{RESULTS}

These results depict the patterns of change in three important functional markers of Leydig cells during the differentiation process. Messenger RNA levels 

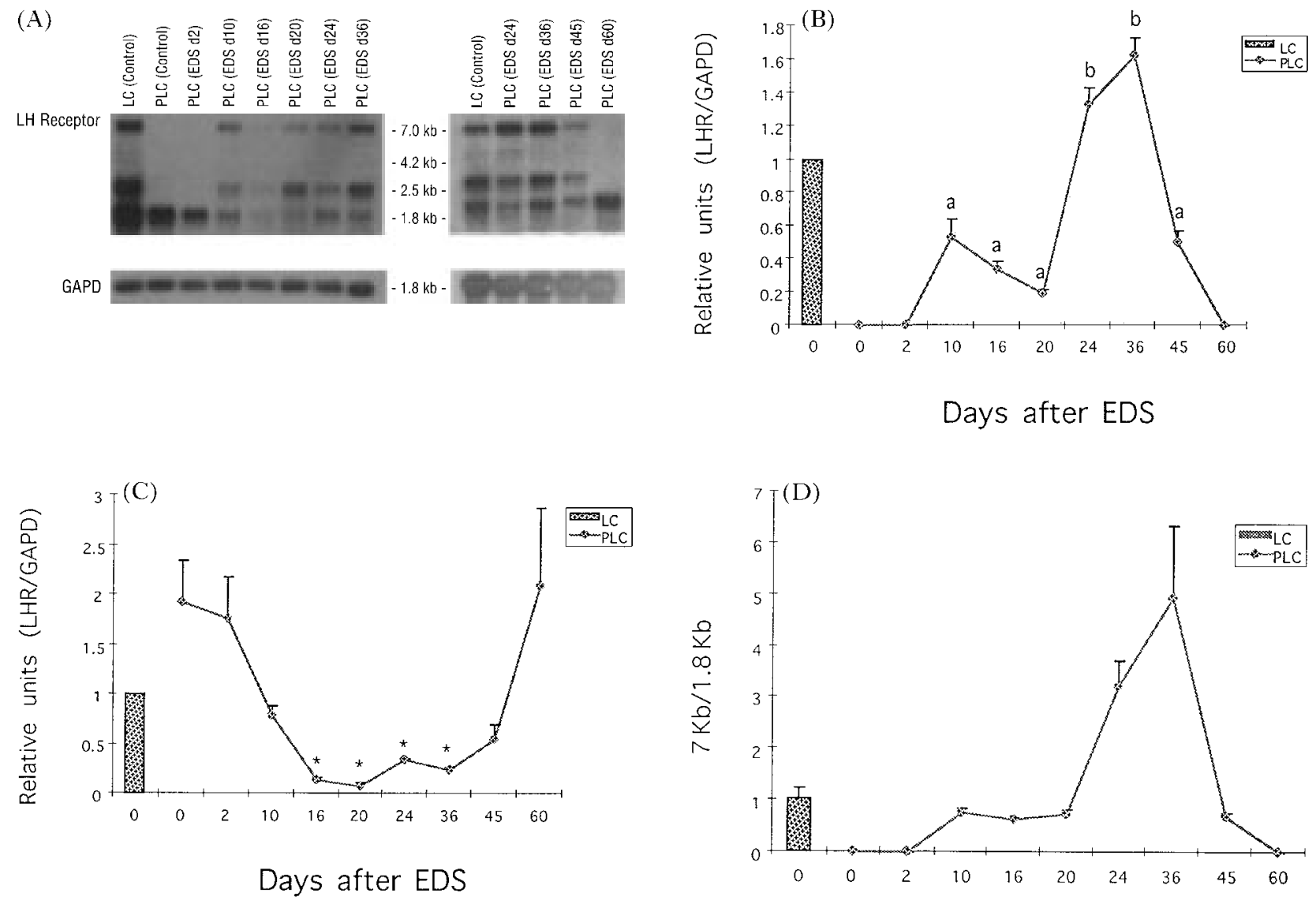

FIGURE 1. Northern blot analysis of the LH receptor in control Leydig cells and precursor cells and in precursor cells after EDS treatment. Twenty micrograms total RNA extracted from the Leydig cell and precursor cell fractions were analyzed as described in Materials and Methods. Northern blot results are shown in (A). The amount of the LH receptor mRNA was standardized to that of the GAPD and assigned a value of 1 in the control Leydig cells. (B) and (C) illustrate the levels of the $7.0 \mathrm{~kb}$ and $1.8 \mathrm{~kb}$ transcripts respectively. The ratio of $7.0 \mathrm{~kb}$ and $1.8 \mathrm{~kb}$ transcripts in the control and EDS-treated groups is shown in (D). The results represent the means \pm s.E.M. from two to seven experiments, each performed using ten rats. In (B) the levels of LHR $7 \cdot 0 \mathrm{~kb}$ transcript from precursor cells of the control and EDS-treated rats were compared by Fisher's LSD $t$-test and values marked a are significantly different from values marked b $(P<0.05)$. In $(\mathrm{C})$ the levels of the $1.8 \mathrm{~kb}$ transcripts in the precursor cells were compared by Dunnett's $t$-test and asterisks indicate significant differences when compared with the control precursor cells.

for LHR, P-450 scc $_{\text {and P-450 }}$ an in and PLC fractions of the control and EDS-treated rats were detected by Northern blot analysis. Levels of the target mRNAs were corrected by that of the internal 'house keeping gene', GAPD.

Northern blot results and quantification of LHR mRNA levels in LC and PLC fractions are shown in Fig. 1. The LC fraction from the control rats expressed all four major transcripts of $\mathrm{LH}$ receptor mRNA, $1 \cdot 8 \mathrm{~kb}, 2 \cdot 5 \mathrm{~kb}, 4 \cdot 2 \mathrm{~kb}$ and $7 \cdot 0 \mathrm{~kb}$ (Fig. 1A). Only the truncated $1.8 \mathrm{~kb}$ transcript was expressed in the PLC fraction of the control rats. At day 10 after EDS treatment, all four transcripts were detected in the PLC fraction (Fig. 1A). At this time, the level of the $7 \cdot 0 \mathrm{~kb}$ transcript of LHR mRNA was $0.52 \pm 0 \cdot 11$ (relative units) in the PLC fraction relative to the control LCs (Fig. 1B). No significant changes of the $7.0 \mathrm{~kb}$ transcript level in the PLC fraction were detected between day 10 and day 20 post-EDS treatment. The amount of the $7 \cdot 0 \mathrm{~kb}$ transcript for LHR increased significantly at day 24 after EDS injection $(1.33 \pm 0.09$ relative to the control LC fraction). The peak value of this transcript was $1 \cdot 62 \pm 0 \cdot 1$ at day 36 post-EDS treatment in the precursor cell fraction. The level of the $7.0 \mathrm{~kb}$ transcript in the PLC fraction decreased 
greatly at day 45 post-EDS treatment and was no longer detected in this fraction at 60 days after EDS administration.

When the amount of the $1.8 \mathrm{~kb}$ transcript mRNA was corrected by GAPD mRNA and assigned a value of 1 for the control LCs, the level of this truncated transcript was $1.92 \pm 0.41$ in the control PLCs (Fig. 1C). PLCs at day 2 post-EDS treatment were also found to express only the $1.8 \mathrm{~kb}$ transcript and the amount of this transcript was not different from that of the control precursor cells (Fig. 1C). In comparison to the changes of $7 \cdot 0 \mathrm{~kb}$ transcript in the PLC fraction, the $1.8 \mathrm{~kb}$ truncated transcript had decreased significantly at day 10 after EDS treatment and reached a nadir between 16 and 36 days post-EDS treatment (Fig. 1C). The levels of this truncated form of $\mathrm{LH}$ receptor mRNA transcript began to increase and returned to the control level at 60 days post-EDS treatment, coinciding with the decrease in the $7.0 \mathrm{~kb}$ transcript in the PLC fraction. The ratio of $7.0 \mathrm{~kb}$ to $1.8 \mathrm{~kb}$ transcript in the control LC fraction was $1 \cdot 02 \pm 0 \cdot 23$ (Fig. 1D). As expected, this ratio rose dramatically during the period of $\mathrm{LC}$ regeneration and peaked at a value of $5 \cdot 0 \pm 1 \cdot 36$ on day 36 post-treatment. Likewise, this ratio dropped as cells in the PLC fraction returned to the undifferentiated stage with expression of only the $1.8 \mathrm{~kb}$ transcript.

The changes in P-450 ${ }_{\mathrm{scc}} \mathrm{mRNA}$ levels in the LC and PLC fractions during differentiation are shown in Fig. 2A and $\mathrm{B}$. The steroidogenic enzyme $\mathrm{P}-450_{\mathrm{scc}} \mathrm{mRNA}$ was detected in the LC fraction of the control testis with a size of $2 \cdot 2 \mathrm{~kb}$. PLCs in the control testis did not express the mRNA for this steroidogenic enzyme; likewise P-450 ${ }_{\text {scc }}$ mRNA was not detected in the PLC fraction at day 2 after EDS injection. PLCs began to express P-450 scc $\mathrm{mRNA}$ at day 10 post-EDS treatment at a level of $0 \cdot 26 \pm 0 \cdot 08$ relative to the control LCs. This low level of $\mathrm{P}-450_{\mathrm{scc}} \mathrm{mRNA}$ was maintained in the PLC fraction between days 10 and 20 post-EDS treatment. P-450 $0_{\mathrm{scc}} \mathrm{mRNA}$ in the PLC fraction increased significantly to a level of $0.75 \pm 0.05$ at day 24 post-treatment and reached the maximum $(0.99 \pm 0.03$ relative to control LCs) at day 36 post-EDS treatment, reflecting the presence of differentiating LCs. The P-450 scc $\mathrm{mRNA}$ level in the PLC fraction then decreased significantly at day 45 and was not detected at day 60 post-EDS treatment, indicating that the PLC fraction no longer contained LCs.

The pattern of change in mRNA levels for $\mathrm{P}-450_{17 \alpha}$, another important LC steroidogenic enzyme, was also investigated. As shown in Fig. 3, Northern blot analysis demonstrated that mRNA of $\mathrm{P}-450_{17 \alpha}$ was expressed in the LC fraction of the
(A)
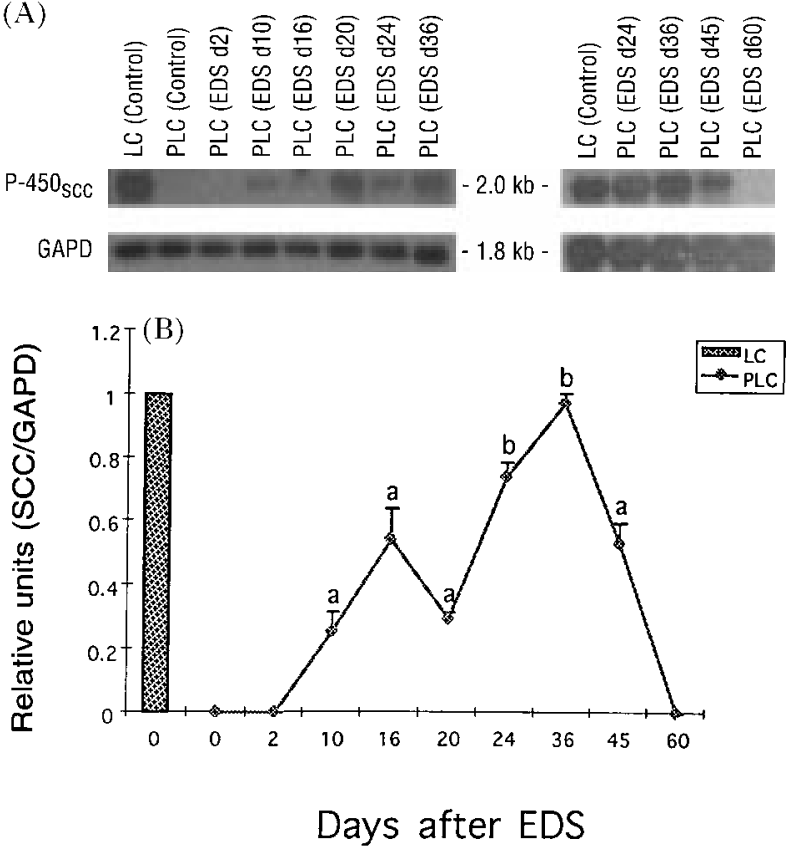

FIGURE 2. Northern blot analysis of P-450 scc in control Leydig cells and precursor cells and in precursor cells after EDS treatment. Twenty micrograms total RNA extracted from the Leydig cell and precursor cell fractions were analyzed as described in Materials and Methods. Northern blot results are shown in (A). The amount of the P-450 $0_{\mathrm{scc}}$ mRNA was standardized to that of the GAPD and assigned a value of 1 in the control Leydig cells. (B) Illustrates the relative units of P$450_{\text {scc }} \mathrm{mRNA}$ in the control and EDS-treated groups. The results represent the means \pm S.E.M. from two to seven experiments, each performed using ten rats. Precursor cells of the control and EDS-treated rats were compared by Fisher's LSD $t$-test. Values marked a are significantly different from those marked b $(P \leq 0 \cdot 05)$.

control rats. Similar to the results obtained for $\mathrm{P}-450_{\text {scc }}$, mRNA for $\mathrm{P}-450_{17 \alpha}$ was not detected in the PLC fraction in the control testis. P- $450_{17 \alpha}$ mRNA also showed a similar pattern to that of $\mathrm{P}-450_{\mathrm{scc}} \mathrm{mRNA}$ during the differentiation process of PLCs. It was not detected in the precursor cell fraction at day 2 after EDS treatment. PLCs began to express $\mathrm{P}-450_{17 \alpha} \mathrm{mRNA}$ at day 10 postEDS treatment $(0 \cdot 74 \pm 0 \cdot 1$ relative to the control LCs). P-450 $17 \alpha$ mRNA levels did not change significantly between day 10 and day 20 post-EDS treatment. At day 24 after EDS treatment, P-450 $17 \alpha$ mRNA increased significantly to $1 \cdot 48 \pm 0 \cdot 14$ relative to the control LCs. It reached a peak value at day 36 post-EDS treatment $(1 \cdot 73 \pm 0 \cdot 12)$ and maintained a high level at day 45 post-EDS 
(A)
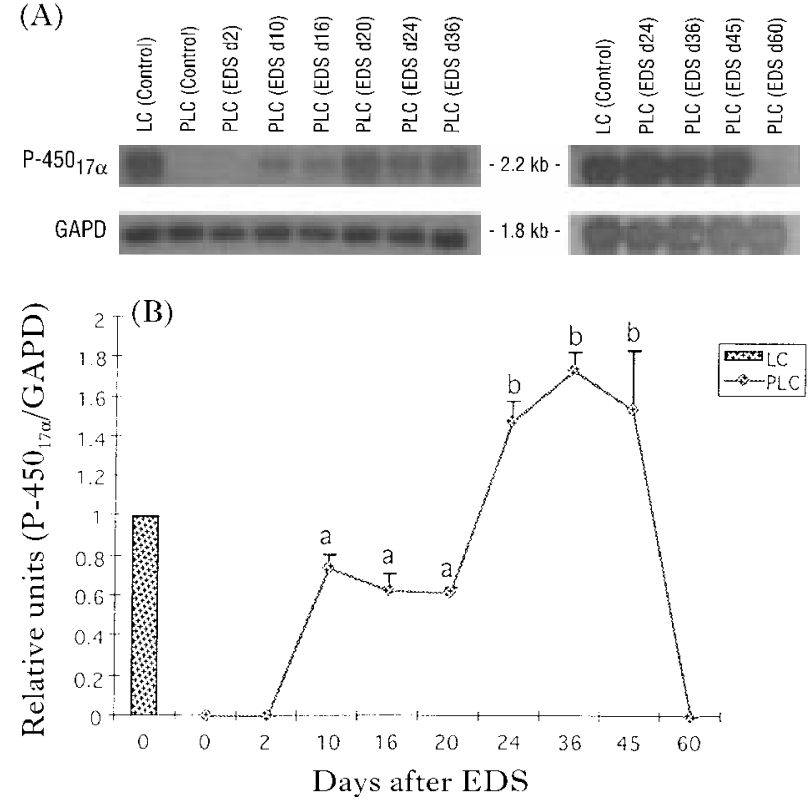

FIGURE 3. Northern blot analysis of P-450 $17 \alpha$ in control Leydig cells and precursor cells and in precursor cells after EDS treatment. Twenty micrograms total RNA extracted from the Leydig cell and precursor cell fractions were analyzed as described in Materials and Methods. Northern blot results are shown in (A). The amount of the P-450 $0_{17 \alpha}$ mRNA was standardized to that of the GAPD and assigned a value of 1 in the control Leydig cells. (B) Illustrates the relative units of P$450_{17 \alpha}$ mRNA in the control and EDS-treated groups. The results represent the means \pm s.E.M. from two to seven experiments, each performed using eight to ten rats. Precursor cells of the control and EDS-treated rats were compared by Fisher's LSD $t$-test. Values marked a are significantly different from those marked $\mathrm{b}$ $(P \leq 0 \cdot 05)$.

treatment, coincident with the process of LC differentiation. Again, gene expression of P-450 $17 \alpha$ was no longer detected in the PLC fraction at day 60 post-EDS treatment.

Finally, to confirm the complete regeneration of LCs at the transcriptional level, total RNA was extracted from the heavier density $(>1.070 \mathrm{~g} / \mathrm{ml})$ LC fraction at days 36 and 60 post-EDS treatment. RNA was subjected to Northern blot analysis using the same cDNA probes discussed above and the results are shown in Fig. 4. As demonstrated in previous studies (Edwards et al. 1988, Risbridger \& Davies 1994), LCs had regenerated by 36 days post-EDS treatment and were again isolated in the heavier Percoll fraction. The levels of LHR and steroidogenic enzyme mRNAs had returned to the control LC values (Fig. 4A and B).

\section{DISCUSSION}

The destructive effect of EDS on testicular LCs in the rat has been well documented (Jackson \& Jackson 1984, Kerr et al. 1987, Myers \& Abney 1990, 1991). Two days after EDS treatment, serum testosterone levels decrease sharply and no histologically recognizable LCs are present in the testis (Jackson et al. 1986, Vreeburg et al. 1988). LC regeneration begins around two weeks after EDS treatment from the differentiation of a population of PLCs (Kerr et al. 1987, Risbridger \& Davies 1994). PLCs isolated from the control testis are undifferentiated and demonstrate very little capacity for testosterone production and human (h) CG responsiveness. After mature LCs are destroyed by EDS injection, however, PLCs in the testis undergo a differentiation process and give rise to a new population of LCs (Risbridger \& Davies 1994, Zhai et al. 1996). LC regeneration is complete by five to seven weeks after EDS treatment, at which time normal testicular morphological structure and physiological function return.

Successful isolation of LCs and PLCs from both immature (Hardy et al. 1990) and EDS-treated mature rats (Risbridger \& Davies 1994) have been reported. In the present study, more than $90 \%$ of the cells in the control LC fraction (density $>$ $1.070 \mathrm{~g} / \mathrm{ml}$ ) were $3 \beta$-HSD positive, indicating a high purity of LCs in this cell fraction. In contrast, the majority of cells in the PLC fraction (density $1 \cdot 064-1.070 \mathrm{~g} / \mathrm{ml}$ ) isolated from the control testis were only faintly stained, with less than $5 \%$ darkly stained cells. At day 20 post-EDS treatment, 93\% of the cells in the PLC fraction were stained, of which $33 \%$ were darkly stained as $3 \beta$-HSD-positive cells. This provides evidence that PLCs in the testis undergo a differentiation process to become steroidogenically active cells after EDS-induced death of the initial LC population. Hardy et al. (1990) also showed that the majority of PLCs isolated from immature rats were faintly stained by $3 \beta$-HSD histochemical analysis and became $3 \beta$ HSD-positive cells after in vitro incubation with hCG for three days. All these results indicate that the cell isolation procedures used to prepare LCs and PLCs are reproducible and yield high purity cell fractions.

LH is the primary tropic factor regulating LC function. LHR has been demonstrated to be present exclusively in LCs in the male rats. The regulation of functional LHR levels in LCs can occur at the transcriptional, post-transcriptional and receptor protein levels. The occurrence of multiple species of LHR mRNA has been of great interest since first reported by McFarland et al. (1989). The full length 
(A)
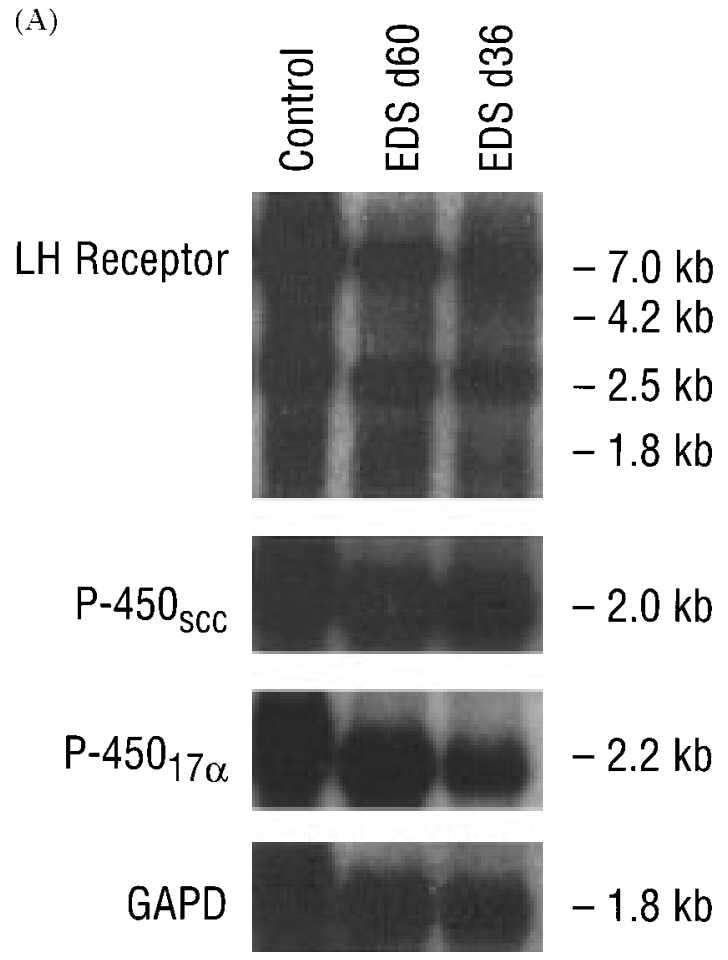

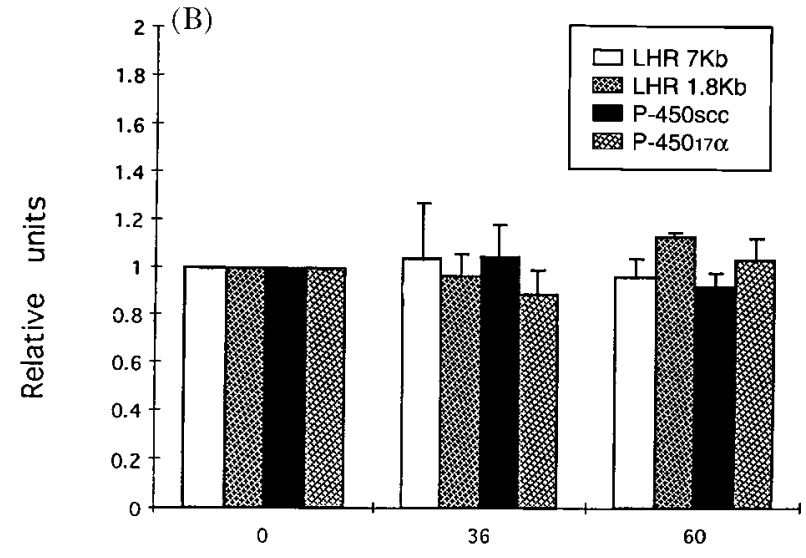

Days after EDS

FIGURE 4. Northern blot analysis of LH receptor, P-450 sec and P-450 $17 \alpha$ mRNA in Leydig cells of the control and days 36 and 60 post-EDS-treated rats. Twenty micrograms total RNA extracted from Leydig cells were analyzed as described in Materials and Methods. Northern blot results are shown in (A). The amount of the target mRNA was standardized to that of the GAPD and assigned a value of 1 in the control Leydig cells. (B) Illustrates the relative units of each mRNA in the control and EDS-treated groups. The results represent means \pm s.E.M. from two experiments, each performed using ten rats. Statistical analysis by ANOVA showed no significant difference among the control and EDS-treated groups.

LHR cDNA is $2.1 \mathrm{~kb}$ and therefore the truncated mRNA forms $(1.2$ and $1.8 \mathrm{~kb})$ cannot be translated into the whole receptor. The major species of LHR mRNA in both the testis and the ovary is the $7 \cdot 0 \mathrm{~kb}$ transcript and the amount of this transcript is correlated with hCG binding capacity in the testis (Vihko et al. 1992). In the present study, the four major mRNA transcripts of LHR $(7 \cdot 0,4 \cdot 2,2 \cdot 5$ and $1.8 \mathrm{~kb}$ ) were detected in the LC fraction of the mature rats. On the other hand, only the truncated form $(1.8 \mathrm{~kb})$ of the transcript was detected in the undifferentiated PLC fraction of the control rats. This truncated form was also the only transcript present in the PLC fraction at day 2 post-EDS treatment. Studies using EDS-treated rats have shown that hCG binding capacity in the testis declined sharply within two days to very low or negligible levels (Jackson et al. 1986, Myers \& Abney 1990). It has been demonstrated that the $1.8 \mathrm{~kb}$ truncated transcript encodes the extracellular domain of LHR and is capable of binding $\mathrm{LH} / \mathrm{hCG}$. However, it remains trapped within the cell rather than being incorporated into the cell's plasma membrane (Segaloff \& Ascoli 1993). Tena-Sempere et al. (1994) demonstrated the presence of this truncated form of LHR mRNA using whole testicular tissue. Using rat testicular interstitial cell preparations, Bhalla et al. (1993) reported previously that only the $1.8 \mathrm{~kb}$ transcript was detectable on days 4 and 10 post-EDS treatment, while all the LHR mRNA transcripts were present after LC regeneration occurred. Using the adult male hypophysectomized, EDS-treated rats in which PLCs do not differentiate into LCs due to the absence of LH, Veldhuizen-Tsoerkan et al. (1994) showed that the $1.8 \mathrm{~kb}$ transcript was the most abundant LHR mRNA species in the testis. Furthermore, Tena-Sempere et al. (1997) reported recently that the $1.8 \mathrm{~kb}$ transcript was associated with the prepolysomal RNA fraction, thus suggesting that it would be translated very inefficiently. These data explain the observation that the testis devoid of LCs after EDS treatment lacks the capacity to bind $\mathrm{LH} / \mathrm{hCG}$, in spite of the expression 
of a truncated form of LHR transcript in the PLCs.

The present study demonstrates that purified PLCs expressed all major mRNA transcripts of LHR at day 10 post-EDS treatment. The levels of the full length transcript $(7 \cdot 0 \mathrm{~kb})$ increased in the PLC fraction between days 10 and 36 after EDS treatment while the truncated form decreased dramatically during this period. We have shown previously (Zhai et al. 1996) that cells in the PLC fraction exhibit an increase in in vitro testosterone production and $\mathrm{hCG}$ responsiveness coincident with the appearance of the $7 \cdot 0 \mathrm{~kb}$ transcript. At day 60 post-EDS treatment, when the regeneration process was completed, the PLC fraction no longer expressed LHR mRNA except for the truncated form and again exhibited little capacity for producing testosterone. These results indicate that PLCs in the rat testis constitutively express the truncated form of LHR. The full length transcripts of LHR are associated with the differentiated function of LCs.

In the LC steroidogenic pathway, transport of cholesterol to the side chain cleavage enzyme $\left(\mathrm{P}-450_{\text {scc }}\right)$ in the inner mitochondrial membrane is the rate-limiting step and, as a labile steroidogenic enzyme, $\mathrm{P}-450_{17 \alpha}$ is very important in the regulation of LC development and function. Our results show that neither of these two critically important steroidogenic enzymes was expressed in the PLCs in the control testis. As early as day 10 post-EDS treatment, the time when the full length LHR mRNA was detected, both $\mathrm{P}-450_{\text {scc }}$ and $\mathrm{P}-450_{17 \alpha}$ were expressed in the PLC fraction. It has been reported that the enzymatic activities of both $\mathrm{P}-450_{\text {scc }}$ and $\mathrm{P}-450_{17 \alpha}$ increase markedly between days 14 and 21 post-EDS treatment (O’Shaughnessy \& Murphy 1991). These increases in the enzymatic activities occur subsequent to the increases in the mRNAs levels.

In the present study, the level of P- $450_{\text {scc }}$ mRNA reached a peak in the PLC fraction between days 24 and 36 post-EDS treatment, decreased significantly thereafter, and was no longer detected by day 60 post-EDS treatment. The pattern of $\mathrm{P}-450_{17 \alpha}$ mRNA changes in the PLC fraction during differentiation was similar to that of $\mathrm{P}-450_{\mathrm{scc}} \mathrm{mRNA}$. It is interesting to note that the patterns for each of the three mRNAs reported in the present study exhibited an initial rise around day 10 , with a nadir around day 20 , followed by a second larger peak at day 36 post EDS-treatment. The significance of this biphasic pattern is unknown, but perhaps it reflects an initial wave of PLC differentiation into LCs followed by a second wave of cell division by the newly formed LCs as reported previously (Hardy et al. 1989,
Myers \& Abney 1991). LHR and steroidogenic enzyme mRNA levels in the LC fraction at days 36 and 60 post-EDS treatment were not significantly different from those of the control LCs, indicating the regeneration of LCs from the differentiation of the PLCs.

In summary, the present study has utilized purified cell fractions from the testis of EDS-treated rats to define the temporal changes in mRNAs for several components that are characteristic of functional LCs. The results demonstrate differentiation at the transcriptional level of PLCs after EDS treatment that are correlated with our previous data of the in vitro testosterone production by the PLC fraction (Zhai et al. 1996). This study further illustrates that expression of a truncated form of the LHR mRNA is a characteristic of the undifferentiated precursor Leydig cells, that expression of the full length LHR and the steroidogenic enzyme mRNAs occurs early during differentiation into functional LCs and that the PLCs subsequently return to the undifferentiated stage.

\section{REFERENCES}

Bartke A, Hafiez AA, Bex FJ \& Dalterio S 1978 Hormonal interactions in regulation of androgen secretion. Biology of Reproduction 18 44-54.

Bhalla VK, Abney TO \& Mahesh VB 1993 Gonadotropin receptor gene expression in regenerating Leydig cells following a single in vivo injection of ethylene dimethylsufonate. Endocrine Fournal $1427-434$.

Edwards G, Robertson WR \& Morris ID 1988 Characterization of the regenerated Leydig cell population of the rat after destruction by ethylene-1,2-dimethanesulphonate. Fournal of Endocrinology 117 11-18.

Hall PF 1985 Trophic stimulation of steroidogenesis: in search of the elusive trigger. Recent Progress in Hormone Research 41 $1-59$.

Hall PF 1991 Cytochrome P450 C21 $1_{\text {scc }}$ : one enzyme with two actions: hydroxylase and lyase. Fournal of Steroid Biochemistry and Molecular Biology 40 527-532.

Hardy MP, Zirkin BR \& Ewing LL 1989 Kinetic studies on the development of the adult population of Leydig cells in the testes of the pubertal rat. Endocrinology 124 762-770.

Hardy MP, Kelce WR, Klinefelter GR \& Ewing LL 1990 Differentiation of Leydig cell precursors in vitro: a role for androgen. Endocrinology 127 488-490.

Jackson AE, O'Leary PC, Ayers MM \& de Kretser KM 1986 The effects of ethylene dimethane sulphonate (EDS) on rat Leydig cells: evidence to support a connective tissue origin of Leydig cells. Biology of Reproduction 35 425-437.

Jackson CM \& Jackson H 1984 Comparative protective actions of gonadotrophins and testosterone against the antispermatogenic action of ethane dimethanesulfonate. Fournal of Reproduction and Fertility 71 393-401.

Kerr JB, Donachie K \& Rommerts FFG 1985 Selective destruction and regeneration of rat Leydig cells in vivo. Cell Tissue Research 242 145-156. 
Kerr JB, Bartlett JMS, Donachie K \& Sharpe RM 1987 Origin of regenerating Leydig cells in the testis of the adult rat. Cell Tissue Research 249 367-377.

Klinefelter GR, Hall PF \& Ewing LL 1987 Effect of luteinizing hormone deprivation in situ on steroidogenesis of rat Leydig cells purified by a multi step procedure. Biology of Reproduction 36 768-783.

McFarland KC, Sprengel R, Phillips HS, Kohler M, Rosemblit N, Nikolics K, Segaloff DL \& Seeburg PH 1989 Lutropin chorio-gonadotropin receptor: an unusual member of the G protein-coupled receptor family. Science $\mathbf{2 4 5}$ 494-499.

Mendis-Handagama SMLC, Risbridger GP \& de Kretser DM 1987 Morphometric analysis of the components of the neonatal and the adult rat testis interstitium. International Fournal of Andrology 10 525-534.

Misrahi M, Beau I, Ghinea N, Vannier B, Loosfelt H, Meduri G, Vu Hai MT \& Milgrom E 1996 The LH/CG and FSH receptors: different molecular forms and intracellular traffic. Molecular and Cellular Endocrinology 125 161-167.

Morris ID, Phillips DM \& Bardin CW 1986 Ethylene dimethanesulfonate destroys Leydig cells in the rat testis. Endocrinology 118 709-719.

Myers RB \& Abney TO 1990 Testosterone and androstanediol production by regenerating Leydig cells in the ethylene dimethane sulphonate-treated rat. International Fournal of Andrology 13 4-16.

Myers RB \& Abney TO 1991 Interstitial cell proliferation in the testis of the ethylene dimethane sulfonate-treated rat. Steroids 56 91-96.

Nakajin S, Shinoda M, Haniu M, Shively JE \& Hall PF 1984 The $\mathrm{C}_{21}$ steroid side-chain cleavage enzyme from porcine adrenal microsome: purification and characterization of the $17 \alpha$-hydroxylase $\mathrm{C}_{17-20}$ lyase cytochrome P-450. Fournal of Biological Chemistry 259 3971-3976.

O’Shaughnessy PJ \& Murphy L 1991 Steroidogenic enzyme activity in the rat testis following Leydig cell destruction by ethylene-1,2-dimethanesulphonate and during subsequent Leydig cell regeneration. Fournal of Endocrinology 131 451-457.

Payne AH, Youngblood GL, Sha L, Burgos-Trinidad M \& Hammond SH 1992 Hormonal regulation of steroidogenic enzyme gene expression in Leydig cells. Fournal of Steroid Biochemistry and Molecular Biology 43 895-906.

Privalle CT, Crivello JF \& Jefcoate CR 1983 Regulation of intramitochondrial cholesterol transfer to side-chain cleavage cytochrome $\mathrm{P}-450_{\mathrm{scc}}$ in rat adrenal gland. Proceedings of the National Academy of Sciences of the USA 80 702-706.

Reiter E, McNamara M, Closset J \& Hennen G 1995 Expression and functionality of luteinizing hormone/ chorionic gonadotropin receptor in the rat prostate. Endocrinology 136 917-923.

Risbridger GP \& Davies A 1994 Isolation of rat Leydig cells and precursor forms after administration of ethane dimethane sulfonate. American Fournal of Physiology 266 E975-E979.

Russell LD, Corbin TJ, Ren HP, Amador A, Bartke A \& Ghosh S 1992 Structural changes in rat Leydig cells post-hypophysectomy: a morphometric and endocrine study. Endocrinology 131 498-508.

Saez JM 1994 Leydig cells: endocrine, paracrine, and autocrine regulation. Endocrine Review 15 574-625.

Segaloff DL \& Ascoli M 1993 The lutropin/choriogonadotropin receptor... 4 years later. Endocrine Review 14 324-347.

Segaloff DL, Sprengel R, Nikolics K \& Ascoli M 1990 The structure of the lutropin choriogonadotropin receptor. Recent Progress in Hormone Research 46 261-303.

Shan LX \& Hardy MP 1992 Developmental changes in levels of luteinizing hormone receptor and androgen receptor in rat Leydig cells. Endocrinology 131 1107-1114.

Tapanainen J, Kupoio T, Pelliniemi LJ \& Huhtaniemi I 1984 Rat testicular endogenous steroids and number of Leydig cells between the fetal period and sexual maturity. Biology of Reproduction 31 1027-1035.

Teerds KJ, Closset J, Rommerts FFG, De Rooij DG, Stocco DM, Colenbrander B, Wensing GJG \& Hennen G 1989 The effects of pure $\mathrm{FSH}$ and $\mathrm{LH}$ preparations on the number and function of Leydig cells in immature hypophysectomized rats. Fournal of Endocrinology 120 97-106.

Tena-Sempere M, Zhang FP \& Huhtaniemi I 1994 Persistent expression of a truncated form of the luteinizing hormone receptor messenger ribonucleic acid in the rat testis after selective Leydig cell destruction by ethylene dimethane sulfonate. Endocrinology 135 1018-1024.

Tena-Sempere M, Rannikko A, Kero J, Zhang FP \& Huhtaniemi IT 1997 Molecular mechanisms of reappearance of luteinizing hormone receptor expression and function in rat testis after selective Leydig cell destruction by ethylene dimethane sulfonate. Endocrinology 138 3340-3348.

Veldhuizen-Tsoerkan MB, Ivell R \& Teerds KJ 1994 hCG-induced changes in the $\mathrm{LH} / \mathrm{hCG}$ receptor mRNA transcript levels in the testis of adult hypophysectomized, ethane dimethyl sulphonate-treated rats. Molecular and Cellular Endocrinology 105 37-44.

Vihko KK, Nishimori K, LaPolt PS \& Hsueh JW 1992 Expression of testicular messenger ribonucleic acid for luteinizing hormone receptor in the rat: developmental regulation of multiple transcripts during postnatal life. Biology of Reproduction 46 1016-1020.

Vreeburg JTM, Oms MP, Rommerts RRG \& Teerds KJ 1988 Functional properties of developing rat Leydig cells after treatment with ethylene dimethanesulphonate (EDS). Fournal of Reproduction and Fertility 84 63-69.

Zhai J, Lanclos KD \& Abney TO 1996 Estrogen receptor mRNA changes during Leydig cell development. Biology of Reproduction $\mathbf{5 5} 782-788$.

REVISED MANUSCRIPT RECEIVED 19 September 1997 